\title{
Safeguarding Insurance in Iowa
}

\author{
By EMORY H. ENGLISH ${ }^{1}$ \\ In Two Parts-Part I
}

Indemnifying arrangements between English shipowners are credited with being the medieval forerunner of more modern insurance institutions. A coffeehouse at an English port, popular because of the accuracy of its weather and fishing news, was the resort of ship owners, brokers and merchants who congregated there. At first, the indemnifying of voyage undertakings with each other, sometimes mutually and at times for concessions or other considerations, constituted the basis of agreements. From that beginning grew marine insurance organizations, the first known form of underwriting, ultimately to insure nearly anything, but starting with ships and their cargoes.

Two hundred and more years have elapsed since America's first insurance company was organized in 1735 at Charlestown, South Carolina. And, illustrating the hazards of even the business, it is recorded that in 1740 a fire destroyed half of Charlestown and the losses incurred ruined the company. Thus, it quickly came to be understood that stability of management, adequacy of premiums and reserves and sound invest. ments, thereby safeguarding the public interest, were vital factors in the conduct of such institutions.

At almost the inception of formal government in Iowa, provision was made authorizing the incorporation of an insurance organization. Later, similar provision was had for others. Subsequently, and quite naturally, came authoritative direction and supervi-

\footnotetext{
${ }^{1}$ The author was a member of three sessions of the Iowa General Assembly, in 1902, 1904 and 1906, and chairman of the house committee on insurance in the last two of those sessions; also was the first state insurance commissioner of Iowa, serving two terms under the appointment by Gov. Geo. W. Clarke, following separation of the department from the office of auditor of state July 1, 1914 .
} 
sion of insurance transactions by the state, both as to domestic organizations and those domiciled in commonwealths other than Iowa.

During the period the writer served as supervising state official, a stockholder in a newly organized Iowa insurance company made personal inquiry with respect to what measure of protection the state gave to him and other stockholders of such corporations. He was advised that, in fact, the legal safeguards were intended for the policyholder and the public interest, to make sure that he and others engaged in that business dealt fairly and were responsible in sufficient degree to make certain of fulfillment of contractural engagements with Iowa citizens and property owners. Quickly he said, "We stockholders do not run the business; that is done by the officers." Whereupon he was advised that the stockholders, or members in case of a mutual organization, were in fact the company, and responsible for its operation and service to the public through the officers whom they had elected and placed in charge. Therefore, the restrictive statutes of the state did apply to men like himself, who chose to be in business and the invested capital of whom was at risk in its conduct and management.

A complete tracing herein of the development of the insurance business in Iowa and its growth and supervision is not contemplated. The phases of legislation first enacted and the companies originally operating thereunder will be illustrative of the beginnings in Iowa of authorized underwriting of various classes of risks. Dating from that early period, such undertakings were under a degree of suspicion by the public, and likewise by some officials because of slight knowledge of the limitations of risks assumed by the insurance organizations.

The great majority of the companies, perhaps nearly all, were honorably and competently managed, but it was largely an unexplored field of activity. Risks assumed with best of intentions in some instances eventually proved to be far greater than justified by the 
small premiums charged, sometimes involving the management in troublesome financial difficulties. Then there were a few unscrupulous men engaging in the business, whom the public was far from qualified to sort out from those of honorable intentions. So, the legislative restrictions and requirements, enacted from time to time, sought to hold those operating the various lines of the business to strict accountability, with provision ultimately for adequate rates, with reserves from which to pay the losses that inevitably occur.

THE FIRST Iowa CoMpany

In the very first session of the Territorial Legislative Assembly the subject was considered. Action was had authorizing the incorporation of the Iowa Mutual Insurance Company "to afford the members thereof the means of mutually insuring each other against loss by fire." This act consisted of thirty-seven sections covering in detail matters now considered as belonging in articles of incorporation. These included powers, persons deemed members, officiary, liability under policies issued and the validity of same, personal liability of members, payment of losses, actions, judgments, and other specified phases of operation, with restrictive provision, however, that no policy be issued until applications for insurance shall have been made to total amount of at least $\$ 30,000$.

While detailed recital herein of all such legislation is not proposed, there is interest in the procedure as set forth in the journals of the territorial council (senate) and the house of representatives, which disclose that Sen. Jonathan W. Parker, representing Scott and Clinton counties, introduced the bill late in the session on December 29, 1838, as Council Bill No. 34. It was amended and passed by the council on January 9, and further amendments adopted by the house, which were concurred in by the council on motion of Sen. Stephen Hempstead of Dubuque county on January 16; and on the 25th, the last day of the session, Sen. Charles Whittlesey of Johnson county, from the joint committee on enrollment, reported the bill having been presented to 
the governor for his signature. The act appeared as a chapter under incorporation in the Statute laws of the Territory of Iowa ${ }^{2}$, published by the secretary of state as certified July 23, 1839.

Thus early, it was recognized that in the complex economic structure of a state, insurance is an institution upon which the stability of the community is largely dependent. In its fundamental principles, and with the proper employment of its functions, insurance commends its self as a reliable and easily available system by which citizens are enabled to provide with certainty for future necessities. In fire insurance the measure of hazard is determined, first by the character of the property insured, its composition, proximity to other property, its contents and use. Other factors likewise indicate the probability of loss being sustained and the degree of protection afforded, all these factors affecting the rate charged therefor, to the end that funds may be available for the expense of company operation, as well as the payment of losses experienced.

\section{KIRKWOod Saw Necessity}

The initial regulatory legislation was secured through Senate File $145,{ }^{3}$ an act to supervise insurance companies, introduced January 12, 1857, by Sen. Samuel J. Kirkwood, of Johnson county, which eventually became Chapter 149, ${ }^{4}$ acts of the Sixth General Assembly, and appeared as Chapter 68, code of 1860 . Included in its provisions were requirements for specified reports to the auditor of state, to whom was given authority to license companies and agents; also provision was made for amount of paid-in capital stock and investment of same, with penalties for violations and non-compliance.

The duties of the auditor of state relating to insur-

${ }^{2}$ Statute Laws of the Territory of Iowa, enacted by First Session of Legislative Assembly, Burlington, 1838-39, pp. 286-291.

${ }^{3}$ Sen. File No. 145, Sixth G.A., original draft in archive files of State Department of History \& Archives.

${ }^{4}$ Session laws, Sixth General Assembly, Chap. 149, pp. 202-208. 
ance supervision were in force from and after July 4, 1857, the effective date of the new law. But, through the succeeding years the powers of that officer, in direction of the insurance business transacted in Iowa, were gradually enlarged, and continued until long after the turn of the century, when the present separate state insurance department was established, effective July 1, 1914, the writer hereof becoming the first insurance commissioner.

The people of Iowa have given credit to former Governor and Senator Kirkwood for much that was of great value to the state, contributed by him during a long public service, but perhaps not all for which this wise and far-seeing statesman was entitled. A man of varied talents, he bulked large in Iowa history, and a brief digression in tracing his course and honors in public life, for the edification of present day students of history, may be helpful.

As a youth Kirkwood was educated in the schools of Washington, D. C., and later taught school in Ohio. He became township assessor and a clerk in a countyseat law office. Afterward, he was admitted to the bar, enjoyed an extensive law practice, and became known as a master logician and orator of ability. He served in the Ohio constitutional convention of 1850 , and eventually came west to Iowa City in 1855, purchased an interest in a mill at Coralville, becoming a miller and a farmer.

Soon, however, his interest in political affairs was revived, although at first aloof from public matters in the new environment. As an avowed anti-slavery advocate he became interested with James W. Grimes and others in the formation of the Republican party in Iowa, and was a delegate to its first convention held at Iowa City February 22, 1856. He was nominated on June 28th following for state senator from the JohnsonIowa county district, as a Republican, and elected that fall, serving in the Sixth and Seventh General Assemblies. He became chairman of the Republican state committee, and both during the campaign and in the 
subsequent legislative work acquired a state-wide acquaintance. As a campaigner he was in great demand and was elected and served two terms, from 1860 to 1864, as Iowa's war governor; then a short term as United States senator, 1866-67, and a third term as governor in 1876-77. While not an announced candidate, he had been persuaded to allow his name to be considered for governor in the Republican state convention in 1875, and was nominated and elected. This was a move against his own best judgment, and its inception rather a sour note in a fine career. The event caused General Weaver, a dynamic and able leader, to leave his party because of the affront-although Kirkwood again proved a most capable executive. The Iowa City Press-Citizen (August 2, 1948) told interesting details of how this was brought about:

\section{ALLISON INFLUENCEd KIRKWOOD}

Iowa political history would not be complete without the lurid tale of how Sen. William B. Allison and his secretary, Jacob B. Rich of Dubuque, rode in a lone Rock Island engine from Des Moines to Iowa City, one night in June, 1875, to see Kirkwood and make sure that he would not refuse to accept the Republican nomination for governor, which the state convention was bent on taking from Gen. James B. Weaver, who had started in the balloting leading with the most delegates. Kirkwood had been obdurate in his declination of the honor, having served most brilliantly as the state's chief executive from 1860 to 1864, and aspired to move on to Washington. Allison is credited with having "softened" him considerably, and although still protesting, when the convention was stampeded for him the next day, he finally accepted the nomination. But that is another story, with no bearing on the subject discussed, except to illustrate the high regard in which this early Iowa statesman was held and his versatility in statecraft.

Subsequently, Governor Kirkwood resigned to become a candidate for the United States senate for the regular four year term, to which he was elected, and later was appointed Secretary of the Interior in President Garfield's cabinet.

Kirkwood's early legislative work, as well as that of later periods, was unique in that he acted constantly in co-operation with other men. He never was a "single 
driver," and always gave others as much or more credit for mutual achievements as he took for himself. A notable example of his breadth of vision and determined action was the authorship credited to him of Iowa's first banking law, authorized by the constitution of 1857 and enacted in the first session of the state legislature held at the new capitol in Des Moines in 1858. Iowa people had opposed banks, but they had been found advantageous and safe in Ohio and Indiana, where the favorable workings of the statute were familiar to Kirkwood. And the law proved a great blessing for Iowa, not a dollar loss to any person being sustained through its operation from the time of its enactment until superseded by the national banking system.

Source of KrRKwood's BrLL

However, this article is intended to deal primarily with the subject of insurance. Even prior to his taking up the banking situation, Senator Kirkwood had perceived the need of regulation and supervision of activities in Iowa of those engaged in the insurance business, and straightway lent a hand in the fashioning of the foundation of Iowa's insurance code.

In the official records of the Sixth General Assembly, on file in the public archives at the state Historical building at Des Moines, access is had to the original insurance bill introduced by him. The forthright and practical methods employed by Senator Kirkwood are shown in his use of the scissors and pastepot, now carefully eschewed by the more modern legislator, who still borrows from convenient sources, of course, but in these latter days has benefit of the services of a secretary and typewriter. The bill shows the care and preservation provided by the state in the Historical department, but also the unavoidable ravages of age, for there are faded ink and yellowed edges of the paper, where exposed in the file. The title and enacting clause were written in a legible hand, below which were pasted the printed sections of insurance law cut from the statutes of Illinois. This source is identified 
by a penned change in the text in a section relating to newspaper publication of the annual statements of insurance companies represented locally by agents, substituting the names of three Iowa cities, "Keokuk, Davenport and Dubuke" for the printed names of Chicago, Peoria and Springfield. However, all were elimininated from the bill as amended and enacted.

It long has been the understanding among those having more intimate relations with the insurance business in Iowa that much of the basic law of this and other midwestern states upon that subject, is very similar to, if not identical with the statutes of New York. If that be true, apparently the routing to Iowa was by way of the neighboring state of Illinois. For many years Iowa code sections of this law bore the number of the session of enactment, though denied the hallmarks of ancestry. The several incidental amendments to the original bill, transcribed in longhand are shown on a separate page; likewise the final paragraphs of the bill and the bill cover sheet, showing the progress in stages of passage by the legislature.

When introduced, Senate File $145^{3}$ was referred to a committee consisting of Lyman Cook, of Des Moines county, Alvin Saunders, of Henry county, and Kirkwood. The committee report was filed on January 17, recommending the amendments, which were adopted and the bill ordered engrossed. Coming from the engrossing committee to the senate January 20, the bill was passed January 21, and messaged to the house of representatives, where it was amended by adding a publication clause and the words, "according to law." It was returned to the senate January 26, and the house amendment concurred in January 28, reported correctly enrolled and sent to the governor who signed it the same day. It was published in the Iowa City Capitol and the Iowa City Republican, and appeared as Article I, Chap. 68, in the code of 1860 .

While not so stated in the title, the act by its specific terms applied only to insurance companies organized to transact fire and fire and marine lines, and the fire 
and fire and marine departments of life companies. It was applicable alike to domestic companies and those domiciled outside Iowa, with practically the same restrictions and general authority continued down through the years, requiring statements filed with both the auditor of state and the clerk of the district court in counties where agents operated.

Domestic companies were required to show amount paid in cash on captal stock, amount not paid and secured by notes endorsed by three parties, amount secured by mortgages or pledges of real estate, the names of stockholders with amount of stock owned by each; also amount of policies outstanding, premium receipts, cash on hand, bills payable and receivable, real estate owned, where located and how obtained, and other detailed information, with provisions for issuance by the auditor of state of certificates of authority for both the companies and their agents. Other than Iowa companies were required to file articles of incorporation, power of attorney to accept service in Iowa, and showing of being possessed of at least $\$ 100,000$ paid-up capital.

\section{Three Iowa Companies}

The report of John Pattee, auditor of state, for the fiscal year ending November 1, 1857, submitted state revenue exhibits and certified in the "Fourteenth statement, ' $E$,' Insurance companies, which have complied with the late law," a total of thirty-three companies which gave their capital stock, amount paid in thereon, etc. Of these three were located in Iowa, as follows:

\begin{tabular}{lrr} 
Name & Authorized Capital & \multicolumn{1}{c}{ Paid In } \\
Muscatine Insurance Company___ & $\$ 40,000.00$ & $\$ 18,252.25$ \\
Iowa Insurance Company, Princeton_.. $26,348.20$ & 84.10 \\
Iowa Insurance Company, Oskaloosa_. & $4,486.12$ & $1,530.93$
\end{tabular}

It is not exactly clear how concerns with this showing of paid-in capital could "comply" with the statutory provisions with $\$ 30,000$ requirement. No fees were reported collected nor taxes spread, the latter being provided in the revenue act appearing as Section 464, 
Chapter 37, Title VI, Code of Iowa, 1851, whereby "insurance companies of every description, except mutual insurace companies, existing in other states and operating in this" were to pay "a tax of one percent, for county purposes and one percent for state purposes upon the amount of premiums taken by them during the year previous in the county where the agent conducts the business."

\section{Special Deposits Early Required}

A carefully drawn and much debated law upon special guarantee fund deposited in any other state or territory by an insurance company transacting business in Iowa, was enacted by the Seventh General Assembly, appearing as Article II, Chapter 68, Code of 1860. By its provisions, the auditor of state was required to withhold certificate of authority permitting such company to transact business in Iowa until a detailed report was made to him as to any amounts so deposited, and requirement that a similar deposit in amount equal to five percent of premiums received in this state, be made here until a total of $\$ 40,000$ is deposited, same to be held as a guarantee fund for payment of Iowa claims in case of insolvency or liquidation, the company to receive the interest or dividends paid upon stocks so deposited.

The act required also that mutual companies incorporated under laws of any other state, must have certification of capital possessed of at least $\$ 100,000$, secured by five times that amount by a lien on real estate not encumbered to more than one-half of cash valuation, before being entitled to receive a certificate of authority to transact business in Iowa. The bill was House File 49, introduced by Repr. William W. Belknap of Lee county, approved by the governor February 9, 1858, and published February 17, 1858.

This, and previous insurance legislation, really applied to out-of-state companies, for very few domestic companies were yet organized. J. W. Cattell, auditor of state, in his report for the biennial period from November 1,1857 , to November 6,1859 , inclusive, included 
among the exhibits, "Eighteenth, Statement 'D'-Insurance companies which have complied with the law in relation thereto;" likewise carrying no itemized list of receipts therefrom. The statement lists forty-two companies "which have complied with the law in relation thereto, their capital stock, liabilities, etc., for the year 1859." Only one company located in Iowa is listed, it being the Muscatine Fire Insurance Company, Capital $\$ 40,000$, Paid in $\$ 40,000$. The amount of assets and liabilities were omitted in the listing.

\section{Confusion in State Funds}

Gov. Ralph P. Lowe, in his message at the close of his administration, in January, 1860, called attention of the Eighth General Assembly to some financial discrepancies in the office of the auditor of state, as indicated by the auditor's reports. He concurred in a recommendation for the adoption of a new and simplified separation of accounts, and the making identical of the fiscal and calendar year, and that a special deputy be assigned to that duty, to the end that confusion of funds be ended.

The revenue act of 1860 , passed April 3, by the Eighth General Assembly, and taking effect July 4, in Chapter 164, provided that "insurance companies of every description, existing in other states and operating in this, shall be taxed one percent for state purposes, upon the amount of premiums taken by them during the year previous to the listing in the county where the agent conducts that business; and the agent shall render the list and be personally liable for the tax; and if he refuses to render the list or to swear as herein required, the amount may be assessed according to the best knowledge and discretion of the assessor." By another provision in the same chapter, mutual insurance companies incorporated under the laws of Iowa, when the principal office of doing business is located in this state, were omitted from the assessments and not taxed. Life insurance was not yet under regulation here.

In Chapter 52, Article I, Sec. 707, laws of the Eighth General Assembly, provision was made that "premium 
notes of mutual insurance companies may be rendered a lien upon the whole or any part of the real estate upon which the property insured is situate, and treated the same as though it were a mortgage."

In the subsequent report by Mr. Cattell, for the biennial period ending November 3, 1861, "Statement E" listed thirty-nine companies operating in Iowa writing fire and marine insurance. The Muscatine Fire Insurance Company was not among them; but a goodly group of new Iowa companies, with limited assets, appeared as follows:

Name

Location

Dubuque

Assets

American Insurance Co. $\$ 15,390.40$

Iowa Mutual Insurance Co. Wyoming $21,019.39$ Independence Insurance Co. Iowa Insurance Co.

Independence $4,568.86$ Oskaloosa $34,438.79$

Auth. Capital \$32,500; Paid in \$8,250

Denmark Mutual Fire Ins. Co._Denmark

Apparently the receiving of the statements filed from year to year for inspection and information, with issuance of company and agent certificates of compliance, largely constituted the extent of supervision attempted, as the reports of the state auditors, as they succeeded each other, disclose no comment or statement of other details for a great many years, nor explanation how these early concerns with limited assets could so qualify to transact business, as apparently they were allowed to do.

\section{Accountabitity For Public Funds}

Governor Kirkwood in his inaugural address on January 11, 1860, recommended a careful study of our revenue system, "with a view to ascertain if it cannot be made more certain and more efficient." $\mathrm{He}$ said further, "The laws should provide for the most rigid and exact accountability of all officers charged with the collection, control or disbursement of the public money. Any vagueness of the laws which permits an officer to retain in his hands, without detection, any portion of the public moneys, or to use them for his private benefit, not only defrauds the revenue, but introduces among officials a laxity of morals highly dan- 
gerous to the public interest. The governor is authorized by a law passed at the last session of the general assembly, to institute a careful examination of the accounts of the state officers once each year, and I have not any doubt that the law will be found beneficial in its operations."

LiFe Insurance Authortzed

The laws of 1857 , as amended, were extended by the Ninth General Assembly by passage of House File 8, introduced by George L. Bass, of Clayton county, so as to include all life insurance companies, whether organized in Iowa or incorporated under the laws of other states doing business within this state, when possessed of a minimum capital of $\$ 100,000$. Also it was required that mutual insurance companies file with the auditor of state a copy of their articles of incorporation, and its officers certify that such company is well worth in unincumbered assets the sum of $\$ 100,000$, over and above all its liabilities and exemptions. This act was approved by Governor Kirkwood March 17, 1862, and appears as Chapter 39, acts of the Ninth General Assembly; but in the Eleventh General Assembly the provision that mutual life insurance companies from other states should have $\$ 100,000$ capital was repealed, however explicitly authorizing them to transact business in Iowa when otherwise complying with the law.

\section{State Auditor's Authortty EnLarged}

Since the initial legislation of a decade previous, authorizing insurance companies to transact business in Iowa, the auditor of state had exercised a minimum of direction of these operations down to 1868. Then the duties and powers of that official were substantially expanded by a rewriting of the general insurance law by the Twelfth General Assembly. This was in response to the urging of Gov. Samuel Merrill, another sturdy Iowa leader who recognized the value of adequate insurance. While thus far Iowa had been more fortunate than many older states in dealing with corporations, through a measure of control exercised, it 
came to be recognized that these business organizations should be amenable to the state which granted charter privileges, and also to the state wherein they operated.

It is to the credit of these Iowa men active in public affairs that early they estimated properly the shortcomings, as well as the benefits, which would characterize the new era in commercial and institutional organization in the new state. It was recognized that Governor Merrill, though a banker and a business man, entertained no hostility to business as such. But his messages as executive reveal his belief in proper safeguards for the protection of those entering contractual relations with the corporations, as well as for their legitimate and successful operation. With regard to a more practical and adequate supervision of the insurance business in Iowa, he said on January $24,1868:^{5}$

The inadequacy of our present insurance law to secure the essential condition of safety and protection to the insured has become a subject of merited discussion. The state is bound to frame its legislation for the control of these corporations in such a way as to exclude from our midst, as far as possible, every company which has not the capital and patronage of the public. The apprehension that such companies do exist, forms sufficient grounds for legislation upon the question.

While our law demands satisfactory guarantees from foreign corporations, doing business in the state, it contains very inadequate provisions for securing the solvency and reliability of domestic companies. The inevitable consequence of this is a distrust of such companies, and a diversion of capital from our state, as estimated by the State Auditor, to the annual amount, of half a million of dollars, which might and ought to be retained at home and made to contribute to the upbuilding of our commonwealth.

That we have reliable companies whose insurance affords security to the property of the people, is the result of individual honesty, rather than the wisdom of the law. But even these fail to receive the patronage proportionate to the merits, because the public has no means of assuring itself of their reliability. Subjected to suspicion by the known in-

${ }^{5}$ Edgar R. Harlan in "The People of Iowa," Vol. II, p. 33. Iowa Legislative Documents for 1868 , Vol. II. 
competency of other companies doing business by their side, which are clothed with equal authority from the state, they are totally unable to compete with the corporations of other states, which are allowed to do business within our limits, only upon compliance with stringent conditions.

I would therefore recommend the enactment of a law requiring that every insurance company organized in the State shall possess a bona fide capital, at least one-fourth of which shall be invested in state or government bonds, and deposited with the state treasurer. As a still further guarantee of their reliability, I would recommend that it be provided that insurance commissioners be appointed or elected at each session of the assembly, who shall be required to make an annual examination of the financial condition of every company in the state, and report the result of their examination. In like manner named as banks under our general law, and insurance companies in many other states, they should be required to publish a periodical exhibit of their transactions. Provisions should also be made for the abatement by summary process, of every company failing to comply with the requirements of the law.

\section{Beneficial Legislation Enacted}

Several bills introduced by Sen. J. W. Cattell, then of Polk county, Repr. John Y. Stone, of Mills county, and others, had as their object the enactments favored by Governor Merrill. From the committees to which these were referred came two substitute bills, one relating to general insurance and one to life insurance, almost completely rewriting therein Iowa insurance law. These bills were considered at length, amended further, finally passed and approved by the executive April 7th and 8th respectively. The acts were published and appeared as Chapters 138 and 173 in the session laws. They greatly expanded the provisions of the revision of 1860 , and acts amendatory thereto relating to formation and operation of insurance companies and their supervision.

Thus was continued in more definite and detailed manner the authority of the auditor of state in supervision of insurance transactions here; also enlarging his duties in relation to reports filed, agents licensed, examination and auditing of companies either by himself or examiners appointed for the purpose, collec- 
tion of fees, publishing of annual statements, checking of claim settlements, examination of assets and disposition of real estate acquired by companies and requirement of a deposit with the auditor of state securities representing at least one-fourth of the paid-up capital stock of Iowa life insurance companies.

The first company to make such deposit was the Equitable Life of Iowa. Its capital was $\$ 100,000$, but it chose to make an initial deposit of $\$ 50,000$, to which it added $\$ 30,000$ in 1871 , and a year later had $\$ 96,000$ with the state auditor. In 1873, the Iowa Life was organized at Keokuk with a capital of $\$ 25,000$, its initial deposit of securities that year being $\$ 25,025$.

In his first annual report of the insurance division, covering years 1868 and 1869, issued in 1870, Auditor of State John A. Elliott said:

Trusting and depending upon life insurance companies and extending to them the long credit we do, how necessary it is that those companies should invest the funds received from us in a safe manner. I am sorry to see a tendency on the part of eastern companies to invest in securities of a doubtful character, among which are railroad bonds, bank stocks and shares of manufacturing companies, all of which are of a fluctuating, sensitive nature, affected by every change of markets. I am proud to say that the law of our own state in regard to investments set a worthy example to our older sister states.

Effort was made in the Thirteenth General Assembly in 1870 to enact legislation creating an insurance department separate from the state auditor's office, and also to require deposit with the state securities representing the entire capital of newly organized companies. However, these changes from the old order, then denied, did come long years subsequently.

It was Senate File 212, by Sen. Edw. M. Bill, that sought to require each stock insurance company organized and doing business in the state, each year at the time of filing its annual statement, to deposit in the office of the state treasurer in notes and mortgages, or United States or state bonds, in an amount twenty-five percent greater than shall be required to reinsure its 
risks in this state, estimating said reinsurance at forty percent of the permiums received on unexpired risks; also, each stock insurance company organized in any other than this state at the time of filing its annual statement, should deposit a like amount in like securities and for like purposes; all for the protection of Iowa policy holders. The bill was read first and second times and referred to the senate committee on incorporations, but subsequently was reported upon adversely.

Sen. Geo. W. Couch introduced Senate File 113 for an act establishing a separate insurance department, to be charged with the execution of the laws relating to insurance, with a superintendent of insurance as chief officer, to be appointed by the governor, by and with the consent of the senate. This official was to perform all the duties previously conferred upon the auditor of state in relation to insurance companies and the formation thereof. Upon passage in the senate, January 1, 1871 was designated as the effective date. In the house the bill was reported favorably by the committee on incorporations, but a motion to take up for consideration was defeated near the close of the session.

\section{Aspirations Brought Criticism}

John A. Elliott, state auditor from 1865 to 1871, developed ambition to become governor. When this became known, considerable opposition was encountered by him, some of it critical of his conduct as auditor. Even in Mitchell county, the home of Elliott, a strong current against him was revealed in a letter to C. C. Carpenter, the leading candidate, from an attorney at Osage. ${ }^{\circ}$ Quickly there were other criticisms. The Iowa City Republican charged that Elliott had "made too much money out of his position of auditor to be entitled to further honors from the people of Iowa." A new statute enacted in $1868,{ }^{7}$ relating to insurance contained a provision that the fees collected under the act were to be paid to the state auditor. The attack of the Republican

${ }^{6}$ Iowa Journal of History, Vol. 48, No. 4, pp. 352-355.

${ }^{7}$ Acts Twelfth G. A., Chap. 138, Sec. 32. 
inferred that Elliott had illegally retained these fees personally. Many other papers including the Marshalltown Times and the Council Bluffs Nonpareil joined in the opposition to Elliott, the Times declaring that "should oily John be elected governor he would clear at least $\$ 100,000$ during his gubernatorial term-and all in a perfectly lawful manner."

The Iowa State Register had pointed out that Elliott was only acting in accordance with the law, that the auditor received only $\$ 1,300$ per year, and that the intention of the law had been for the auditor to collect the fees in question to supplement his small salary. The article in the Register, February 3, 1871, was under the heading "Authorship of Law Disavowed by Elliott," as follows:

At that time the salary of the auditor and secretary of state was $\$ 1,300$, a mere pittance for the men occupying those positions. When the law was passed, no one had any thought that the insurance business in Iowa would so soon assume so gigantic proportions as it has under the workings of this wholesome law, and that as the secretary of state received special fees in the matter of notarial commissions, affixing seals, etc., amounting in the year to not an inconsiderable sum, it was but just that the fees accruing from the insurance department should be disposed of the same as in the office here mentioned. At the last session of the legislature a law was enacted raising the salaries of the state officers, cutting off all those fees and directing them into the state treasury, and the insurance law remained unchanged.

There were rumors that Elliott would sue some of the critical papers; but there were no libel suits and Elliott's chances of further political preferment were damaged badly by this episode, and eventually he retired from the gubernatorial contest. The ambiguity of the law relating to insurance fees was not corrected for many years and remained to plague subsequent auditors and some of their employees.

The Register, however, highly compliments Elliott, saying, "Mr. Elliott has rendered the public valuable service;" adding, "under his direction it has been a source of large revenue to the state, and the rights and interests of the people become carefully guarded." Elliott 
was credited with authorship of a new law requiring examination of insurance companies.

Chicago Fire Hit Companies

John Russell became state auditor in January, 1871. He personally, devoted much time to insurance supervision, encountering many vexatious problems, not the least of which were inaccuracies of reports filed by companies and even misstatements. In his report of March 31 of that year, he criticized out-of-state companies for delays in the filing of their annual statements with the department.

In Governor Merrill's final message to the Fourteenth General Assembly delivered January 10, 1872, he mentioned "the conflagrations of October, 1871, being so great, involving losses of hundreds of millions of dollars worth of property ... and failure of many insurance companies was feared."

Auditor Russell had made special inquiry of fire insurance companies licensed to operate in Iowa, relative solvency, and as a result "arrived at the conclusion that nearly one-half of those admitted to Iowa would have to refrain from transacting business here." This was occasioned by losses incurred in the great Chicago fire of October 8 and 9, 1871, and therefore he revoked the authority of thirty-two companies and ordered them to immediately suspend doing business in Iowa.

At meetings of two national conventions of insurance supervisory officials, there had been considered a draft of a uniform insurance law suggested for enactment in all states. The governor then recommended that "whatever changes are made or new provisions introduced into our insurance law, no company, home or foreign, be permitted to do business in the state without a paid-up capital of at least $\$ 50,000 . "$

In this session Repr. James Van de Venter introduced another bill, House File 317, again seeking to establish an insurance bureau to have charge of and regulate insurance separate from the state auditor's office. The bill was referred to the house committee on insurance, 
the report of which recommended its indefinite postponement, and this action was taken.

Repr. Geo. C. Heberling introduced H.F. 325 seeking additional protection for holders of policies of life insurance companies, which failed of passage, and on reconsideration, after a spirited fight on the floor, again lacked sufficient votes.

In the same session Repr. J. L. Williams secured passage of H.F. 194 restricting payment of salaries to officers, employees and agents of mutual insurance companies.

Sen. Samuel McNutt, chairman of the committee on ways and means, introduced and obtained passage of Senate File 265, an act further regulating insurance companies, amending chapters of the insurance code enacted by the Twelfth General Assembly. Capital stock requirements for companies from outside the state were raised from $\$ 100,000$ to $\$ 200,000$ and their certificates of solvency not to be considered conclusive; naming the American Experience Table of Mortality, and four and one-half per cent interest as the basis of standard valuation of life policies. Provision was made for a new schedule of fees and taxes to be collected from non-Iowa companies, the tax to be two and onehalf percent of the gross amount of premiums received in this state. Thus the authority of Iowa supervision was being strengthened, as well as its income increased.

\section{ReCIPROCITY URGED bY CARPENTER}

In a special message to the legislature, submitted by Gov. Cyrus C. Carpenter, March 8, 1872, he said in part ${ }^{8}$ covering uniform insurance legislation recommended by former Governor Merrill:

Upon the subject of life and fire insurance legislation, and covering the draft of a proposed law in relation thereto ... in the main the same as that prepared by the National Convention of State Insurance Officers, appears to meet the demands of the public. It is aimed to secure, in so far as practicable, reciprocal legislation among the several states upon this subject, an object the accomplishment of which I cannot

${ }^{8}$ Iowa Legislative Documents, 1872, Vol. II. 
but deem eminently desirable. The present I consider an opportune time for the presentation of this measure.

Auditor of State John Russell had attended the national meetings referred to by Governor Merrill, which adopted forms of statements to be made to state insurance departments by insurance companies, and seriously recommended uniform systems of supervision by the states. The current rate of taxation of insurance premiums in Iowa at that time was two percent for fire companies and none at all for life companies. The auditor recommended that a uniform rate of one and onehalf percent on gross premium receipts be paid thereafter, over one million dollars in premiums having been collected in Iowa by life companies in 1870, upon which tax was being paid to other states, but none to Iowa. The proposed rate for Iowa companies was to be less than for those located outside the state, for the purpose of encouraging the building up of home organizations.

The Fifteenth General Assembly, beginning its sessions in January, 1874, received a number of bills having to do with insurance subjects, none of which secured passage excepting Senate File 28, by Sen. Albert Boomer, relating to life insurance, being largely a re-writing of the law, specifying requirement of a license from the auditor of state by an agent before his directly or indirectly taking risks or collecting premiums, or in any manner transacting the business of life insurance in the state; also requiring companies to submit statements and secure certificates of compliance with law before taking risks in Iowa.

\section{Clatms Caused Company Withdrawals}

Auditor of State John Russell complained in his annual report of April, 1874, that companies were withdrawing from the state by reason of vexatious law suits brought by individuals in Dubuque county arising from delayed filing of annual statements, but were discontinued when the time for filing was extended by law to April 1. Also he reported that twenty life and fire companies had retired from the state, and the fact 
that they filed no statements and he had no means of knowing how much business they may have done, he could safely estimate that the aggregate premiums received by all companies would be "over two and onehalf million dollars-a sum over three times as much as the entire state tax levy for one year." This he said, indicated "the interest our people have in the insurance business in all its branches is large and importantmuch greater than they are required to invest in the whole machinery of state government."

And the honesty of annual statements filed were in some instances again called into question, Mr. Russell saying in conclusion:

When the management of any kind of business falls into the hands of unprincipled men, we have almost daily evidence that to them oaths are no very formidable barriers to rapacity, fraud and public theft. The overpowering vice of the present age seems to be the inordinate desire to rapidly accumulate wealth without corresponding labor. To gratify this insane mania, men violate public trusts, sacrifice reputations, destroy true manhood, disregard most sacred oaths, and voluntarily go into moral bankruptcy for life-terrible prices thus paid for a phantom. The insurance interest no doubt has its fair share of this class of men engaged in it; hence we may expect occasional instances where false representations will be made in these sworn statements. Let us hope, however, that these form rare exceptions to the rule.

Extension of the details of supervision by the state came in the more frequent examinations of insurance companies by the auditor of state. The Sixteenth General Assembly in 1876 enacted a provision of law that the necessary expenses of any such examination made or ordered to be made by the auditor of state, should be certified by him, and paid on his requisition by the company which is the subject of such examination. The bill was House File 135, introduced by Repr. John L. Morse.

And another new law relating to life insurance, House File 196, by Repr. John Gibbons, was calculated to prevent injustice to the assured in connection with examining physician's certificate, condition of health, 
misstatement of age and process of collection of difference in premium charge.

In 1877, Auditor of State Buren R. Sherman secured the services of former Auditor John Russell, to make examination of Iowa companies, saying "his long experience with the business, his established character throughout the state as a man of strict integrity, was sufficient guaranty that the work would be well and thoroughly done, and his findings merit the confidence of the people." Mr. Russell made these examinations, including the auditing of company statements, and proved "that the confidence of the people in our home organizations has not been misplaced."

The auditor of state was given power by the Seventeenth General Assembly in 1878, to examine the form of all policy contracts sold to Iowans and to see that same contained provision for cancellation upon equitable terms upon the request of the assured, with penalties for violation of the law. This act was the subject of Senate File 258, by the committee on insurance, H. C. Hemenway, chairman, and became Chapter 39, acts of that assembly.

\section{Deposit of Securuties With State}

In this same session, the law covering character of investments of life insurance companies domiciled in Iowa, and requiring deposit of securities of specified character with the auditor of state in amount representing the ascertained reserve value of policies in force, was rewritten and broadened, greatly strengthening supervisory authority over assets. In one form or another this law has remained in force throughout intervening years, becoming renown in assuring the stability of Hawkeye insurance organizations. The bill was introduced as Senate File 160 , by Senator Hemenway, and became Chapter 47 of the laws of that assembly.

The custody by the state of securities representing these assets has naturally become somewhat burdensome, but important in the extreme. The vital principle so fundamental in insurance is that security over- 
shadows all other considerations, and the state does well to lend its functions to complete safeguarding of the integrity of the assets of its insurance institutions, although the responsibility involved is tremendous. Restrictive in a degree this regulation has never been onerous to companies, though at times provisions by the state for housing the mounting volume of these valuable documents, have hardly been as adequate or convenient as might be desired. However, in the vaults provided in the new state office building, ample vault room is afforded.

Indicative of the growth of Iowa companies the increasing volume of these deposits with the state insurance department tells its own story and indicates the tremendous responsibility of the state. For a number of years after the first enactment became effective requiring deposits, the sums representing assets of the various companies were small as compared with the huge total of these deposits of $\$ 1,422,124,518.80$ as of June 30, 1954. From the records it is found that at various periods down through the intervening years the aggregate mount of securities on deposit each year indicated was as follows:

\begin{tabular}{|c|c|c|c|c|}
\hline 69 & 50 & 1918 & - & .01 \\
\hline 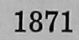 & 80 & 1925 & & 228 \\
\hline & & 1930 & & \\
\hline & 417, & 1935 & & .30 \\
\hline & (No & 19 & & \\
\hline & (No Re & 1945 & & 6,343.64 \\
\hline & $32,881,310.33$ & 1950 & & $1,099,926,913.03$ \\
\hline & $56,790,095$ & 19 & & $1,422,124,518$. \\
\hline
\end{tabular}

Three Des Moines life companies held substantial bulk of the above, on June 30,1954 , as follows:

Bankers Life Company. $\$ 626,893,194.87$ Equitable Life of Iowa ___ $416,065,178.65$ Central Life Assurance Society ___ 110,823,280.80

Another bill introduced in the Seventeenth General Assembly, was Senate File 122, by Sen. Henry C. Carr, substituted for a code section, becoming Chapter 104 , acts of that session, limiting the powers of mutual insurance companies. Annual reports were provided 
for, with requirement that they should pay the same fees as other insurance organizations, with explicit provision that no foreign life company, aid society, or association for the insurance of lives of its members and doing business on the assessment plan, should be allowed to do business in the state unless it had a guaranteed capital of not less than $\$ 100,000$ in the state in which it was organized.

\section{The "Valued Policy" Law}

The "valued policy' legislation for fire risks by the 18th General Assembly in 1880 came as the result of many contested claims. House File 176, by Repr. Samuel F. Simpson, being of a restrictive nature, besides providing that "the amount stated in the policy be prima facie the actual coverage, and the company be liable for the full value so stated," also required a copy of the application to be attached to the policy, and neglect to do so precluded the company from pleading or proving contents of such application or representations. This act also made the individual soliciting the insurance an agent of the company issuing the policy. The act became Chapter 211, laws of the Eighteenth General Assembly.

Another restrictive law by this assembly was House File 157, by Warren S. Dungan, being entitled "an act to secure policy holders in fire insurance companies from unjust forfeitures of policies," provision being made for specific manner of giving notice when premiums became due, and requiring short-rate method of cancellations, the act becoming Chapter 210, laws of the same assembly.

A short provision was authorized by House File 118, by Repr. William Lake amending the code in relation to so-called "mutual aid or benevolent societies," making money payable by them not liable for debts of the decedent member of such society.

And in his annual report of 1880, Auditor Sherman said, "In Iowa, although more business has been done than during the preceding year, it has been less remunerative ... The margin for profits has been small 
indeed, and effectually disposes of the points made in many quarters that the insurance companies are draining the state of its means, and making no adequate return to the unfortunate sufferers."

Then, in 1881, the new state auditor, W. V. Lucas, rather proudly commented in his report: "The [insurance] companies doing business in the state are stronger and safer, as a rule, than in any previous report, thus giving better and more reliable security to the insured ... They are well established, and have proven themselves worthy of confidence... Insurance is an absolute necessity for the protection of business. That it is so recognized is not debatable." Here we have trust and confidence rather than pessimistic outlook. Lucas showed aptitude and capacity in banking and insurance supervision to the extent of statutory requirements.

\section{Feared Concerns Without Reserves}

The prevailing tendency of lodge organizations with insurance divisions to operate without adequate supervision deeply concerned Auditor W. V. Lucas, who said in his biennial report of 1881, "If there is no check placed upon this kind of wildcat insurance, it is only a question of a short time when disaster will overtake them. I have discouraged such enterprises. I have held that all such organizations are insurance companies and they should make report to this department and comply with the law, depositing three-fifths of their annual premiums in this office as a sinking fund for the benefit of the insured."

Governor Gear in his second biennial message of January 10,1882 , emphasized the need of curbing these outlaw concerns, saying:"

"As these companies refuse to make any report to the auditor, and are contesting by law the right of the state to control them, there is, in my mind, fair reason for believing the organizations not to be legitimate in their objects, but on the contrary intended to be the source of large gains to those controlling the so-called

${ }^{8}$ Iowa Legislative Documents, 1882, Vol. I. 
insurance companies, at the expense of the unwary and unsuspecting, who take it for granted that any concern having the words 'Insurance Company,' on its door or in its so-called policies is organized under the provisions and requirements of law, which are complied with by insurance companies doing a legitimate business. The organization of this class of companies should, in my judgment be strictly forbidden by law, for it is certain, if some check is not placed upon them, serious abuses will creep in, such as have been in vogue in other states ... I trust you will apply such remedial legislation as will prevent anything of the kind in this state... The insurance business is constantly increasing, and any legislation throwing additional safeguards round the rights of the policy holder is certainly in the right direction. The general public, who pay their money for insurance, must of necessity rely on the protection the state affords the policy holder through its legislation."

To remedy this situation House File 436, by Repr. Chas. A. Bishop, of Black Hawk county, to regulate cooperative life insurance companies, was introduced and recommended for passage by the committee on insurance, but failed to obtain a third reading.

Auditor Lucas had also recommended that the minimum of capital for companies organized in Iowa should be $\$ 100,000$, in which the governor concurred, further suggesting that all capital of such companies be paid up.

Auditor Lucas made further suggestion, supported by the recommendation of the governor, that "the best interests of the state and the insurance business would be served by the creation of the office of commissioner of insurance, to whom all matters pertaining to fire, life or other insurance should be committed. An officer with no other branches of business intrusted to his control can do far better," said Mr. Lucas, "in managing the intricate affairs of insurance than can one whose attention is necessarily divided by several important trusts, as is that of auditor of state." 


\section{Assessment Life Companies Cancelled Out}

Auditor of State John L. Brown upon assuming his office January 1, 1883, held that the certificates of authority previously issued to four mutual co-operative assessment life insurance organizations had been erroneously issued, and he was unable to honor same or credit "the so-called securities" deposited previously by them, thereupon cancelling all such authority of those companies and their agents to transact business in Iowa, leaving the Equitable Life Insurance Company of Iowa the only local organization remaining in legal operation here. The deposit of securities of that company was the only one retained.

Brown earnestly urged the establishment of a separate insurance department, which the legislature failed to provide and in his report of the transactions of 1883 , referred to his "attempt at supervision of insurance by the auditor of state, under the laxness and uncertainty of the laws upon that subject."

Mr. Brown charged "that Section 1160 of the code has been left upon the statute books in its present form, as a shield and hiding place for innumerable schemes for speculative robbery and deliberately planned frauds without let or hindrance, the auditor of state having no authority nor power or control over them, is nothing short of a calamity." He critically observed that "the state of Iowa has no Insurance department, and the details of the insurance business must necessarily be intrusted to one of the clerks of the auditor's office."

The report to the governor and the general assembly was lengthy and argumentative, and assured them that he "had begun the examination of our home companies, and the work will be prosecuted with vigor ... until the work is accomplished or until my present official relations shall terminate."

It was during the Brown administration that controversy arose over enforcement by him of retaliatory charges to the out-of-state companies for fees and taxes. Suits in mandamus were instituted against Auditor Brown by several of the insurance companies, 
the deposits of which he refused, but the court sustained him in the rulings made, applying to all associations of the class and character referred to.

And, Gov. Buren R. Sherman, who previously had served as auditor of state, in his first biennial message to the Nineteenth General Assembly, in January, 1882, echoed and endorsed previous recommendations, and suggested that the banking division in the auditor's office be also separated, and the new department created be styled commissioner of banks and insurance, adding, "The insurance interests of the state are already of vast importance-sufficiently so to require the personal attention of a special officer designated therefor, if the state would assure to the people that protection which they expect and demand."

Governor Sherman renewed this recommendation in his second biennial message delivered January 14, 1886, saying that every state auditor for twelve years had urged this change, and that "the time has now arrived when it could no longer be delayed, as the business has become of vast proportions." Also, he took cognizance of need to strengthen the law authorizing examinations of insurance companies, "which clearly needs amendment so far as respects charges for such services, and I suggest that the itemized bill of expenses therefor shall not only receive endorsement of the officer in control as now provided, but shall also be submitted to the approval of the executive council ... I strongly urge early action in these regards. I think this too, a matter of grave importance."

In the Twentieth General Assembly held in 1884, the law authorizing organization of mutual companies was amended by Senate File 295, by Sen. Wm. Larrabee, to include "or loss or damage by tornadoes, lightning, hailstorms, cyclones or wind storms."

\section{Auditor and Governor Clash}

John L. Brown was auditor of state when Buren R. Sherman was governor. Friction arose between them and friends of the men conceded that it was on account of something personal. But, again it was fees that fur- 
nished the spark and mutual insurance the issue. After many disagreements and after Brown's refusal to report certain fees as ordered to do by the governor, Sherman issued an order removing Brown from office, March 19, 1885; he was exacting and extremely critical. Brown refused to vacate and the whole capitol building, located where the Soldiers and Sailors monument now stands, became the scene of military action. Governor Sherman called out the National Guard and filled the old statehouse with soldiers. Citizens were admitted only on military passes. In fact, the old statehouse was actually in a state of siege. Both the governor and the auditor were acting on the advice of their attorneys and each claimed to be within his rights. The controversy in every conceivable form reached the courts.

The state legislature gave recognition to the difficulty and articles of impeachment were preferred by the house against Brown. Impeachment managers were appointed and the trial was before the state senate, lasting for a number of weeks, resulting in the acquittal of Brown upon every count. Before the impeachment, however, Brown had been removed from office and Jonathan W. Cattell was acting auditor of state.

Brown finally was restored to his office and served out his term. He did not aspire to a third term. In defending his opinion, Brown was courageous and stubborn. His trial was a notable one and eminent attorneys from over the state were engaged in the controversy. It was a great legal battle. It was the first impeachment trial in the history of the state, and being reported in detail by the newspapers, attracted widespread attention.

The growth of Iowa life insurance companies and the requirement of adequate reserves, prompted legislation in the Twenty-first General Assembly in 1886, in House File 307, by Repr. Jas. G. Berryhill, requiring the auditor of state to ascertain the net value of each policy issued and in force upon the basis of the American Experience table of mortality and four and one-half percent interest, or actuary's combined table 
and four per cent interest. This made necessary the services of an actuary in the employ of the state, but who would be paid by the companies for whom service was rendered, which was duly authorized. When the amount of the valuation was ascertained by the actuary, the auditor of state was required to notify the company of same, and within thirty days said company was required to deposit with the auditor securities of the character described by law, in total amount of the ascertained valuation of all policies in force, representing the invested funds of the individual company. This act became Chapter 169, laws of the Twentyfirst General Assembly.

Gov. Wm. Larrabee, in his message as chief executive, added his voice to the urgings of previous executives that an insurance department be created, stating in his first inaugural address delivered January 14, 1886, that "owing to the growth of this business the auditor of state is overburdened with this work... The present seems an opportune time to make this change, which has been repeatedly recommended by my predecessors." Also, he urged that "Home companies, being entirely under our control, should be encouraged to do this business at a reasonable rate of compensation. It would seem that Iowa capital and Iowa enterprise should be able to insure Iowa property as safely as nonresident companies. The character of the property in our state is such as should entitle the insured to lower rates than are at present obtained ... Home companies are more likely to do justice to their patrons, being nearer to them, and feeling therefore a greater sense of responsibility."

\section{LARRABeE's Astounding Statement}

Indicative of the widespread misinformation on the part of people generally upon the subject of insurance and the character of service rendered, as well as the necessary process of operation, Gov. William Larrabee, who after twelve years previous service in the Iowa senate, made this astounding statement in his first inaugural address: 
The insurance business of the state has grown to great proportions, about four million dollars being now annually paid in premiums. The losses paid during the last year amounted to less than $\$ 1,600,000$, thus leaving in the hands of the insurance companies over $\$ 2,400,000$ as gross profits. Allowing $\$ 400,000$ to the companies for taxes and contingent expenses, there would be left to them $\$ 2,000,000$ for the labor performed ...

In view of the intelligence of the people of this state, further comments seem unnecessary, although I am well aware that sophistical arguments will be resorted to, to counteract the force of this statement.

Of course, there is no such profit in the insurance business, and was not at that time, for the governor wholly overlooked the requirement to set aside reserves to be invested and held in accumulation for the purpose of payment of losses, and in case of life contracts, the fulfillment of the various future benefits provided, as well as the setting up of unearned premium reserves.

The financial statement filed by a leading American life insurance company ${ }^{10}$ that perpetuates the name of one of the nation's founding fathers and first signer of the Declaration of Independence, carries a statement illustrating the disposition of their policy-holder's dollars for the year 1949, it being as follows:

82.6\% paid to or set aside in reserve for policy holders and beneficiaries;

$8.2 \%$ paid for compensation to field force (agents and supervisors);

$6.9 \%$ required for administrative and all other operating expenses;

$2 / 3 \%$ required for Federal, state and other taxes and fees.

In his second biennial message delivered to the Twenty-third General Assembly February 13, 1890, Governor Larrabee confined his insurance recommendation to a restatement of the need of the state that its insurance business be entrusted to the supervision of a separate state department. He particularly called attention to the responsibility of the state for strict supervision of these interests, and expressed belief that the

${ }^{10}$ Annual Report, 1949, John Hancock Life Insurance Company. 
charging of one official with that work alone would best obtain the desired end.

However, the only new law of general importance pertaining to insurance enacted at that session was House File 407, by Repr. James E. Blythe, of Mason City, to prevent discrimination in life insurance premiums paid or rates charged, or in dividends paid, or in benefits, or any other terms or conditions of such contracts, and agents were prohibited from making rebates or any valuable considerations or inducements in securing applications for policies. This act became Chapter 33, laws of that assembly.

Unmistakable evidence has accumulated through the years that the individual citizen, and sometimes men in high official station, have only meager conception of the principles and requirements inherent and necessary in conducting the business of insurance. All should know that not only must the policy premium be sufficient to pay the agent's commission and the losses and expenses of the insurance organization for any current year in which the payment may be received, but must include a sufficent additional sum to apply upon reserves adequate for future requirements in meeting payments to policy holders provided by the policy contract. This is fundamental, and so recognized by the well informed, particularly those carrying large lines of insurance protection upon lives, property and business undertakings, including hazards of suretyship, perils of transportation and calamities of every nature subject to coverage.

\section{Governments Depend Upon Men}

William Penn once said: "Governments rather depend upon men than men upon governments. Let men be good and the government cannot be bad. But, if men be bad, let the government be ever so good, they will endeavor to warp and spoil it." 
Copyright of Annals of Iowa is the property of State of Iowa, by \& through the State Historical Society of Iowa and its content may not be copied or emailed to multiple sites or posted to a listserv without the copyright holder's express written permission. However, users may print, download, or email articles for individual use. 